\title{
Anti-gouty arthritis and anti-hyperuricemia properties of celery seed extracts in rodent models
}

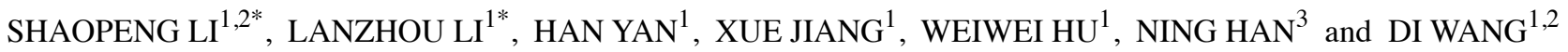 \\ ${ }^{1}$ School of Life Sciences, Jilin University, Changchun, Jilin 130012; \\ ${ }^{2}$ Zhuhai College of Jilin University, Jilin University, Zhuhai, Guangdong 519041; ${ }^{3}$ Department of Ophthalmology, \\ The Second Hospital of Jilin University, Jilin University, Changchun, Jilin 130041, P.R. China
}

Received February 6, 2019; Accepted July 31, 2019

DOI: $10.3892 / \mathrm{mmr} .2019 .10708$

\begin{abstract}
Gout is a type of serious arthritis that is caused by hyperuricemia. Celery is an umbelliferous plant that was shown to exhibit anti-inflammatory activity in rodent. The present study aimed to investigate the effects and potential preliminary mechanisms of celery seed aqueous extract (CSAE) and celery seed oil extract (CSOL) for gout treatment. The components of CSAE and CSOL were systematically analyzed. In mice with hyperuricemia induced by potassium oxonate and yeast extract, CSAE and CSOL treatment reduced the serum levels of uric acid and xanthine oxidase. In addition, CSAE and CSOL reduced the levels of reactive oxygen species and increased the serum levels of superoxide dismutase and glutathione peroxidase in mouse serum. In rats with acute gouty arthritis induced by intra-articular injection of monosodium urate crystals, CSAE and CSOL treatment alleviated the swelling of the ankle joints and reduced inflammatory cell infiltration around the ankle joints. In addition, CSAE and CSOL reduced the levels of interleukin (IL)- $1 \beta$ and tumor necrosis factor $\alpha$ and increased the levels of IL-10. The results of the present study suggested that celery seed extracts may have anti-gout properties, partially through anti-inflammatory and antioxidative effects.
\end{abstract}

\section{Introduction}

Gout is a common form of arthritis associated with pain, fatigue and high fever (1). According to epidemiological studies, the

Correspondence to: Dr Ning Han, Department of Ophthalmology, The Second Hospital of Jilin University, Jilin University, 218 Ziqiang Street, Changchun, Jilin 130041, P.R. China

E-mail: hanning@jlu.edu.cn

Professor Di Wang, School of Life Sciences, Jilin University, 2699 Qianjin Street, Changchun, Jilin 130012, P.R. China

E-mail: jluwangdi@outlook.com

*Contributed equally

Key words: celery seed, hyperuricemia, acute gouty arthritis, oxidative stress, inflammation incidence of gout increased from $1.42 \%$ in 1997 to $2.49 \%$ in 2012 in Britain (2), which is partly influenced by dietary changes and age (3). Hyperuricemia, defined as a level of serum uric acid (UA) $>6.8 \mathrm{mg} / \mathrm{dl}$, is caused by the overactivation of xanthine oxidase (XO) following excessive purine intake (4,5). High levels of UA contribute to the deposition of monosodium urate (MSU) in joints and other tissues (6). The deposition of MSU in the joint cavity activates inflammatory cytokines, inducing the accumulation of macrophages and neutrophils, which leads to gouty arthritis $(7,8)$. Oxidative stress serves an important role in the pathogenesis of gout (9) and is responsible for a series of inflammatory events (10), such as the production of interleukin (IL)-1 $\beta$ (11).

Based on the pathogenesis of gout, inhibiting inflammation and lowering the serum UA level are considered to be effective treatment strategies. Colchicine (COL), corticosteroids and non-steroidal anti-inflammatory drugs are commonly used in the treatment of gouty arthritis $(12,13)$. Allopurinol and febuxostat (FBX) are the main clinical agents for treating hyperuricemia $(14,15)$. However, a number of adverse effects have been reported, including liver damage, nephrotoxicity, bone marrow suppression and hypersensitive bodily reactions (14-16). It is therefore particularly important to find alternative treatment agents for hyperuricemia and gouty arthritis.

Natural products have received increasing attention in clinical applications owing to their diverse efficacies and low adverse effects (17). Celery is an annual or perennial umbelliferous plant widely distributed in subtropical and tropical regions of Europe, Africa and Asia (18). Celery has exhibited antifungal, anti-inflammatory and anti-gastric ulcer effects in rodents, and may lower blood pressure in patients with hypertension (19-23). n-Butanol extracts from celery seeds have been reported to improve lipid peroxidation through antioxidation in diabetic rats (24). Methanol and petroleum extracts from celery seeds reduced blood UA levels in rats (25). However, the antioxidant and anti-inflammatory activities of celery seeds, especially their aqueous extracts and volatile oil, have not been fully reported in gout.

Rats with acute gouty arthritis, which was induced by MSU to simulate acute gout in humans, have been used to investigate the effects of various agents on joint swelling and inflammation (26). Mice with hyperuricemia, which was 
induced by yeast extract powder and potassium oxonate (OXO) to simulate hyperuricemia in humans, have been used to investigate compounds that lower UA level (27). Based on our previous study, the two animal models can be used together to investigate the anti-gout activity of various compounds (28). The aim of the present study was to systematically analyze the main components of the aqueous extract and volatile oil of celery seeds and to determine their anti-gout effects in mice with hyperuricemia and rats with acute gouty arthritis. The specific roles of the antioxidant and anti-inflammatory activities of the aqueous extract and volatile oil of celery seeds were also investigated.

\section{Materials and methods}

Preparation of celery seed aqueous and oil extracts using supercritical carbon dioxide. To prepare celery seed aqueous extract (CSAE), 30 g celery seed powder (Changchun Yonglong Food Co., Ltd.) was added to $300 \mathrm{ml}$ distilled water and heated at $80^{\circ} \mathrm{C}$ for $2.5 \mathrm{~h}$ twice. The supernatants from different samples were collected by centrifugation at 7,100 $\mathrm{x} \mathrm{g}$, at $20^{\circ} \mathrm{C}$ for $10 \mathrm{~min}$ and pooled together. CSAE powder was prepared using a R206 rotary evaporator spray drier (Shanghai Senco Technology Co., Ltd.). The extraction rate of CSAE was $10.0 \pm 0.5 \%(\mathrm{w} / \mathrm{w})$.

To prepare celery seed oil extract (CSOL), 300 g celery seed powder was placed in a HA221-50-06 supercritical carbon dioxide extraction system (Nantong Wenao Import And Export Co., Ltd.) under the following conditions: $35^{\circ} \mathrm{C}$ and $25 \mathrm{MPa}$ in the extraction tank; $40^{\circ} \mathrm{C}$ and $8 \mathrm{MPa}$ in the first separation; and $30^{\circ} \mathrm{C}$ and $6 \mathrm{MPa}$ in the second separation. The extraction period was $2 \mathrm{~h}$, and the oil was collected every $15 \mathrm{~min}$. The extraction rate of CSOL using supercritical carbon dioxide was $7.8 \pm 0.3 \%(\mathrm{w} / \mathrm{w})$.

\section{Composition analysis of CSAE and CSOL}

Main components analysis. The main components of CSAE powder, including total sugar, mannitol, reducing sugar, protein, crude fat, total flavonoids and total triterpenes were determined, as previously described, by the phenol sulfuric acid method (29), high-performance liquid chromatography (30), 3,5-dintrosalicylic acid reducing sugar assay (31), Kjeldahl method (32), Soxhlet extractor method (33), aluminum trichloride colorimetric method (34) and vanillin-glacial acetic acid-perchloric acid colorimetric method (35), respectively.

Fatty acid analysis. A 5\% KOH-methanol solution was added to the CSAE powder or CSOL, incubated in a $60^{\circ} \mathrm{C}$ water bath for $30 \mathrm{~min}$ and mixed with $14 \% \mathrm{BF}_{3}$-methanol solution at $60^{\circ} \mathrm{C}$ for $3 \mathrm{~min}$. The samples were mixed with hexane and the levels of fatty acids were analyzed using a QP2010 gas chromatography-mass spectrometer (Shimadzu Corporation). GC was performed using high-pressure-55\% phenyl methyl siloxane chromatographic column $\left(30 \times 0.32 \mathrm{~mm}^{2}\right.$; diameter, $0.25 \mu \mathrm{m})$. The sample inlet temperature was set at $270^{\circ} \mathrm{C}$, and the column temperature at $100^{\circ} \mathrm{C}$. The heating rate was set at $10^{\circ} \mathrm{C} / \mathrm{min}$ to $170^{\circ} \mathrm{C}$, and at $3^{\circ} \mathrm{C} / \mathrm{min}$ to $250^{\circ} \mathrm{C}$. The carrier gas used was helium, with a flow rate of $2.4 \mathrm{ml} / \mathrm{min}$ at $0.4 \mathrm{MPa}$. For mass spectrometry, electron positive ionization was used as ion source, and the transition was $\mathrm{m} / \mathrm{z} 380.0 \rightarrow 20.0$, the temperature of ion source was $200^{\circ} \mathrm{C}$, the interface temperature was $250^{\circ} \mathrm{C}$, the solvent removal time was $1.5 \mathrm{~min}$, and the detector voltage was $1.14 \mathrm{kV}$.

Amino acid analysis. The CSAE powder and CSOL were hydrolyzed with $6 \mathrm{~mol} / 1 \mathrm{HCl}$ at $110 \pm 1^{\circ} \mathrm{C}$ for $22 \mathrm{~h}$. Following vacuum drying, the samples were dissolved in $1 \mathrm{ml} \mathrm{pH} 2.2$ buffer (19.6 g sodium citrate and $16.5 \mathrm{ml}$ hydrochloric dissolved in 11 of deionized water; $\mathrm{pH} 2.2$ ). The amino acid content was quantified by an L-8900 automatic amino acid analyzer (Hitachi High-Technologies Corporation).

Mineral analysis. The CSAE powder was pretreated with hydrogen nitrate $110^{\circ} \mathrm{C}$ and $3 \mathrm{MPa}$ for $30 \mathrm{~min}$. The levels of mercury, lead, selenium, arsenic, cadmium, zinc, iron, manganese, chromium, calcium, copper, sodium and potassium were detected by inductively coupled plasma optical emission spectrometry as previously described (36-38).

Flavonoid analysis. The flavonoid content of CSOL was analyzed using the Agilent 1260 LC system with a diode array detector-fluorescence detector and a C-18 column (150x4.6 mm; particle size, $5 \mu \mathrm{m}$ ) (Agilent Technologies, Inc.) with the injection volume of $10 \mu \mathrm{l}$ and the flow rate of $1 \mathrm{ml} / \mathrm{min}$ by elution containing $98 \%$ methanol and $2 \%$ ultrapure water at $20^{\circ} \mathrm{C}$. The standards were obtained from Shanghai Yuanye Bio-Technology Co. Ltd.

Animal experiments. The working concentrations of FBX and COL were selected according to previous studies $(39,40)$. Celery seed treatment doses were selected following preliminary experiments (data not shown).

Establishment of mouse hyperuricemia model and drug treatment. A total of 120 male BALB/c mice (age, 8 weeks; weight, 18-20 g) were provided by Liaoning Changsheng Biotechnology Co., Ltd. All mice were housed in plastic cages at $23 \pm 11^{\circ} \mathrm{C}$ with $55 \%$ relative humidity, a 12-h light/dark cycle (7:00-19:00) and standard food and sterile mineral water ad libitum.

Mice were divided into two main groups: i) To investigate CSAE (AE); and ii) to investigate CSOL (OL). Mice used as control to examine CSAE were defined as 'CTRL (AE)' mice; mice used as control to examine CSOL were defined as 'CTRL (OL)' mice. A total of 60 mice were randomly divided into 5 groups ( $\mathrm{n}=12$ mice/group): i) Control [CTRL (AE)] mice group, which received $10 \mathrm{ml} / \mathrm{kg}$ saline by gavage; ii) hyperuricemia model mice [MC (AE)] group, which received $10 \mathrm{ml} / \mathrm{kg}$ saline by gavage; iii) positive control [FBX (AE)] group, which were MC mice that received $0.6 \mathrm{mg} / \mathrm{ml} \mathrm{FBX} \mathrm{(Jiangsu} \mathrm{Wanbang}$ Biochemical Pharmaceutical Group Co., Ltd.) at $10 \mathrm{ml} / \mathrm{kg}$ by gavage; iv) low-dose CSAE-treated model (CSAE-low) group, which received $75 \mathrm{mg} / \mathrm{kg}$ CSAE (equal to $0.75 \mathrm{~g}$ celery seed) dissolved in $10 \mathrm{ml}$ saline by gavage; and v) high-dose CSAE-treated model (CSAE-high) group, which received $300 \mathrm{mg} / \mathrm{kg}$ (equal to $3 \mathrm{~g}$ celery seed) dissolved in $10 \mathrm{ml}$ saline by gavage. CTRL (AE), MC (AE) and FBX (AE) were used as untreated control, model control and positive control groups, respectively, in the experiments analyzing the effects of CSAE in hyperuricemia model mice. 
Table I. Composition of celery seed aqueous extract.

\begin{tabular}{|c|c|}
\hline Component & Compound \\
\hline \multirow{7}{*}{$\begin{array}{l}\text { Main } \\
\text { component }\end{array}$} & Total sugar \\
\hline & Total triterpenes \\
\hline & Mannitol \\
\hline & Reducing sugar \\
\hline & Crude fat \\
\hline & Protein \\
\hline & Total flavonoids \\
\hline \multirow[t]{38}{*}{ Fatty acid } & Capric acid (C10:0) \\
\hline & Undecanoic acid (C11:0) \\
\hline & Lauric acid (C12:0) \\
\hline & Tridecanoic acid (C13:0) \\
\hline & Myristic acid (C14:0) \\
\hline & Myristoleic acid (C14:1n5) \\
\hline & Pentadecanoic acid (C15:0) \\
\hline & Pentadecenoic acid (C15:1n5) \\
\hline & Hexadecanoic acid (C16:0) \\
\hline & Palmitoleic acid $(\mathrm{C} 16: 1 \mathrm{n} 7)$ \\
\hline & Heptadecanoic acid (C17:0) \\
\hline & Heptadecenoic acid $(\mathrm{C} 17: 1 \mathrm{n} 7)$ \\
\hline & Stearic acid (C18:0) \\
\hline & Oleic acid (C18:1n9) \\
\hline & Elaidic acid (C18:1n9t) \\
\hline & Linoleic acid (C18:2n6c) \\
\hline & Trans-linoleic acid (C18:2n6t) \\
\hline & $\alpha$-linolenic acid (C18:3n3) \\
\hline & $\gamma$-Linolenic acid (C18:3n6) \\
\hline & Arachidic acid (C20:0) \\
\hline & Paullinic acid (C20:1) \\
\hline & Eicosadienoic acid (C20:2) \\
\hline & Eicosatrienoic acid (C20:3n3) \\
\hline & $\begin{array}{l}\text { Dihomo- } \gamma \text {-linolenic acid } \\
(\mathrm{C} 20: 3 \mathrm{n} 6)\end{array}$ \\
\hline & Arachidonic acid (C20:4n6) \\
\hline & Eicosapentaenoic acid \\
\hline & (C20:5n3) \\
\hline & Heneicosanoic acid (C21:0) \\
\hline & Docosanoic acid (C22:0) \\
\hline & Erucic acid (C22:1n9) \\
\hline & cis-13,16-Docosadienoic acid \\
\hline & methyl ester (C22:2) \\
\hline & Docosahexaenoic acid \\
\hline & $(\mathrm{C} 22: 6 \mathrm{n} 3)$ \\
\hline & Tricosanoic acid (C23:0) \\
\hline & Tetracosanoic acid (C24:0) \\
\hline & Nervonic acid (C24:1n9) \\
\hline & Octanoic acid (C8:0) \\
\hline \multirow[t]{5}{*}{ Amino acid } & Aspartic acid \\
\hline & L-Threonine \\
\hline & Serine \\
\hline & Glutamic acid \\
\hline & Glycine \\
\hline
\end{tabular}

Table I. Continued.

Content $(\%)$

\begin{tabular}{|c|c|c|}
\hline Component & Compound & Content $(\%)$ \\
\hline \multirow{25}{*}{ Minerals } & Alanine & $1.32 \times 10^{-1}$ \\
\hline & Cysteine & $3.52 \times 10^{-1}$ \\
\hline & Valine & $0.77 \times 10^{-1}$ \\
\hline & Methionine & $2.00 \times 10^{-1}$ \\
\hline & Isoleucine & $1.17 \times 10^{-1}$ \\
\hline & Leucine & $1.88 \times 10^{-1}$ \\
\hline & Tyrosine & $0.69 \times 10^{-1}$ \\
\hline & Phenylalanine & $15.35 \times 10^{-1}$ \\
\hline & Lysine & $0.89 \times 10^{-1}$ \\
\hline & Histidine & $4.77 \times 10^{-1}$ \\
\hline & Arginine & $0.77 \times 10^{-1}$ \\
\hline & Proline & $3.95 \times 10^{-1}$ \\
\hline & Mercury & ND \\
\hline & Lead & $0.18 \times 10^{-4}$ \\
\hline & Selenium & ND \\
\hline & Arsenic & $0.19 \times 10^{-4}$ \\
\hline & Cadmium & ND \\
\hline & Zinc & $29.94 \times 10^{-4}$ \\
\hline & Iron & $36.16 \times 10^{-4}$ \\
\hline & Manganese & $21.50 \times 10^{-4}$ \\
\hline & Chromium & $1.92 \times 10^{-4}$ \\
\hline & Calcium & $2,426 \times 10^{-4}$ \\
\hline & Copper & $2.05 \times 10^{-4}$ \\
\hline & Sodium & $1,258 \times 10^{-4}$ \\
\hline & Potassium & $8,079 \times 10^{-4}$ \\
\hline
\end{tabular}

ND, not detected.

$103.81 \times 10^{-4}$

$54.82 \times 10^{-4}$

$61.99 \times 10^{-4}$

ND

ND

$98.90 \times 10^{-4}$

$115.07 \times 10^{-4}$

$120.20 \times 10^{-4}$

$71.64 \times 10^{-4}$

$88.04 \times 10^{-4}$

$107.84 \times 10^{-4}$

$119.11 \times 10^{-4}$

ND

$106.60 \times 10^{-4}$

ND

ND

$0.02 \times 10^{-4}$

$2.38 \times 10^{-1}$

$1.68 \times 10^{-1}$

$0.22 \times 10^{-1}$

$2.55 \times 10^{-1}$

$1.08 \times 10^{-1}$

The remaining 60 mice were randomly divided into 5 groups ( $\mathrm{n}=12$ mice/group): i) CTRL (OL) group, which received $5 \mathrm{ml} / \mathrm{kg}$ of olive oil by gavage; ii) MC (OL) group, which received $5 \mathrm{ml} / \mathrm{kg}$ of olive oil by gavage; iii) FBX (OL) group, which comprised MC mice that received $6 \mathrm{mg} / \mathrm{kg}$ FBX dissolved in $5 \mathrm{ml}$ olive oil by gavage; iv) low-dose CSOL-treated (CSOL-low) model group, which received $0.058 \mathrm{ml} / \mathrm{kg}$ CSOL (equal to $0.75 \mathrm{~g}$ celery seed) in $5 \mathrm{ml}$ olive oil by gavage; and v) high-dose CSOL-treated (CSOL-high) model group, which received $0.233 \mathrm{ml} / \mathrm{kg}$ (equal to $3 \mathrm{~g}$ celery seed) in $5 \mathrm{ml}$ olive oil by gavage. CTRL (OL), MC (OL) and FBX (OL) were used as untreated control, model control and positive control groups, respectively, in the experiments analyzing the effects of CSOL in hyperuricemia model mice.

With the exception of the CTRL mice, $12 \mathrm{~h}$ prior to the oral administration of the aforementioned agents (saline, olive oil, FBX, CSAE or CSOL), $20 \mathrm{~g} / \mathrm{kg}$ yeast extract powder was administered by gavage to the mice once a day for 8 days. On day 6,7 and $8,1 \mathrm{~h}$ prior to the oral administration of the aforementioned agents, mice were intraperitoneally injected with $300 \mathrm{mg} / \mathrm{kg}$ OXO (Sigma-Aldrich; Merck KGaA) to induce hyperuricemia (28); the CTRL mice were injected with $0.9 \%$ saline following the same schedule. During the 8 days, the aforementioned agents (saline, olive oil, FBX, CSAE, CSOL 
Table II. Composition of celery seed oil extract.

\begin{tabular}{|c|c|c|}
\hline Component & Compound & Content $(\%)$ \\
\hline \multirow[t]{35}{*}{ Fatty acid } & Capric acid (C10:0) & $0.118 \times 10^{-2}$ \\
\hline & Undecanoic acid (C11:0) & $0.029 \times 10^{-2}$ \\
\hline & Lauric acid (C12:0) & $1.315 \times 10^{-2}$ \\
\hline & Tridecanoic acid (C13:0) & $0.059 \times 10^{-2}$ \\
\hline & Myristic acid (C14:0) & $9.120 \times 10^{-2}$ \\
\hline & Myristoleic acid (C14:1n5) & $0.013 \times 10^{-2}$ \\
\hline & Pentadecanoic acid (C15:0) & $1.033 \times 10^{-2}$ \\
\hline & Pentadecenoic acid (C15:1n5) & $0.049 \times 10^{-2}$ \\
\hline & Hexadecanoic acid (C16:0) & $983.766 \times 10^{-2}$ \\
\hline & Palmitoleic acid $(\mathrm{C} 16: 1 \mathrm{n} 7)$ & $8.086 \times 10^{-2}$ \\
\hline & Heptadecanoic acid (C17:0) & $4.521 \times 10^{-2}$ \\
\hline & Heptadecenoic acid (C17:1n7) & $3.506 \times 10^{-2}$ \\
\hline & Stearic acid (C18:0) & $242.853 \times 10^{-2}$ \\
\hline & Oleic acid (C18:1n9) & $115.324 \times 10^{-2}$ \\
\hline & Elaidic acid (C18:1n9t) & ND \\
\hline & Linoleic acid (C18:2n6c) & $5,174.071 \times 10^{-2}$ \\
\hline & Trans-linoleic acid (C18:2n6t) & ND \\
\hline & $\alpha$-linolenic acid (C18:3n3) & $320.313 \times 10^{-2}$ \\
\hline & $\gamma$-Linolenic acid (C18:3n6) & $0.436 \times 10^{-2}$ \\
\hline & Arachidic acid (C20:0) & $21.331 \times 10^{-2}$ \\
\hline & Paullinic acid (C20:1) & $6.764 \times 10^{-2}$ \\
\hline & Eicosadienoic acid (C20:2) & $1.579 \times 10^{-2}$ \\
\hline & Eicosatrienoic acid (C20:3n3) & $0.435 \times 10^{-2}$ \\
\hline & $\begin{array}{l}\text { Dihomo- } \gamma \text {-linolenic acid } \\
(\mathrm{C} 20: 3 \mathrm{n} 6)\end{array}$ & $0.114 \times 10^{-2}$ \\
\hline & Arachidonic acid (C20:4n6) & $1.543 \times 10^{-2}$ \\
\hline & $\begin{array}{l}\text { Eicosapentaenoic acid } \\
(\mathrm{C} 20: 5 \mathrm{n} 3)\end{array}$ & $0.035 \times 10^{-2}$ \\
\hline & Heneicosanoic acid (C21:0) & $1.082 \times 10^{-2}$ \\
\hline & Docosanoic acid (C22:0) & $21.793 \times 10^{-2}$ \\
\hline & Erucic acid (C22:1n9) & $0.257 \times 10^{-2}$ \\
\hline & $\begin{array}{l}\text { cis-13,16-Docosadienoic acid } \\
\text { methyl ester (C22:2) }\end{array}$ & $0.211 \times 10^{-2}$ \\
\hline & $\begin{array}{l}\text { Docosahexaenoic acid } \\
(\mathrm{C} 22: 6 \mathrm{n} 3)\end{array}$ & $0.084 \times 10^{-2}$ \\
\hline & Tricosanoic acid (C23:0) & $2.165 \times 10^{-2}$ \\
\hline & Tetracosanoic acid (C24:0) & $9.214 \times 10^{-2}$ \\
\hline & Nervonic acid (C24:1n9) & $0.053 \times 10^{-2}$ \\
\hline & Octanoic acid (C8:0) & $0.251 \times 10^{-2}$ \\
\hline \multirow[t]{13}{*}{ Amino acid } & Aspartic acid & 0.007 \\
\hline & L-Threonine & ND \\
\hline & Serine & 0.003 \\
\hline & Glutamic acid & ND \\
\hline & Glycine & 0.001 \\
\hline & Alanine & ND \\
\hline & Cysteine & ND \\
\hline & Valine & ND \\
\hline & Methionine & 0.003 \\
\hline & Isoleucine & ND \\
\hline & Leucine & ND \\
\hline & Tyrosine & ND \\
\hline & Proline & 0.112 \\
\hline
\end{tabular}

Table II. Continued.

\begin{tabular}{llc}
\hline Component & \multicolumn{1}{c}{ Compound } & Content $(\%)$ \\
\cline { 2 - 3 } & Lysine & 0.003 \\
& Arginine & 0.007 \\
& Histidine & 0.004 \\
& Phenylalanine & $\mathrm{ND}$ \\
& Dihydromyricetin & $\mathrm{ND}$ \\
& Myricetin & $\mathrm{ND}$ \\
& Naringenin & $0.18 \times 10^{-2}$ \\
& Apigenin & $0.012 \times 10^{-2}$ \\
& Taxifolin & $0.52 \times 10^{-2}$ \\
& Eriodictyol & $0.032 \times 10^{-2}$ \\
& Luteolin & $0.024 \times 10^{-2}$ \\
& Aromadendrin & $0.095 \times 10^{-2}$ \\
& Quercetin & $2.3 \times 10^{-2}$ \\
& Kaempferol & $\mathrm{ND}$ \\
\hline
\end{tabular}

ND, not detected.

or COL) were administered every day. On day 8 , after the last administration of the agents, over $150 \mu \mathrm{l}$ of blood were collected from the caudal vein of all mice, and then the mice were sacrificed. Liver samples were collected from all mice post mortem. In summary, yeast extract powder was administered by gavage once a day.

Establishment of rat acute gouty arthritis model and drug treatment. A total of 120 male Wistar rats (age, 8 weeks; weight, 180-220 g) were obtained from Liaoning Changsheng Biotechnology Co., Ltd. All rats were housed in plastic cages at $23 \pm 11^{\circ} \mathrm{C}$ with $55 \%$ relative humidity, a 12 -h light/dark cycle (7:00-19:00) and ad libitum access to standard food and mineral water.

A total of 60 rats were randomly divided into 5 groups ( $\mathrm{n}=12$ rats/group): i) CTRL (AE) group, which received $5 \mathrm{ml} / \mathrm{kg}$ saline by gavage for 8 days; ii) rat gouty arthritis $\mathrm{MCr}$ (AE), which receive $5 \mathrm{ml} / \mathrm{kg}$ saline by gavage for 8 days; iii) positive control [COL (AE)] model group, which received $0.4 \mathrm{mg} / \mathrm{kg}$ COL (Yunnan Phytopharmaceutical Co., Ltd.) dissolved in $5 \mathrm{ml}$ saline by gavage for 8 days; iv) SAE-low group, which received $50 \mathrm{mg} / \mathrm{kg}$ CSAE (equal to $0.5 \mathrm{~g}$ celery seed) dissolved in $5 \mathrm{ml}$ saline by gavage for 8 days; and v) CSAE-high group, which received $200 \mathrm{mg} / \mathrm{kg}$ (equal to $2 \mathrm{~g}$ celery seed) dissolved in $5 \mathrm{ml}$ saline by gavage for 8 days. CTRL (AE), $\mathrm{MCr}$ (AE) and COL (AE) were used as the untreated control, model control and positive control groups, respectively, in the experiments analyzing the effects of CSAE in gouty arthritis model rats.

The remaining 60 rats were randomly divided into 5 groups (n=12 mice/group): i) CTRL (OL) group, which received $1 \mathrm{ml} / \mathrm{kg}$ olive oil by gavage for 8 days; ii) $\mathrm{MCr}(\mathrm{OL})$ group, which received $1 \mathrm{ml} / \mathrm{kg}$ olive oil by gavage for 8 days; iii) COL (OL) group, which was model rats that received $0.4 \mathrm{mg}$ COL dissolved in $1 \mathrm{ml} / \mathrm{kg}$ olive oil by gavage for 8 days; iv) CSOL-low group, which received $0.039 \mathrm{ml} \mathrm{CSOL}$ ( $0.5 \mathrm{~g}$ celery seed) dissolved in $0.961 \mathrm{ml} / \mathrm{kg}$ olive oil by gavage 

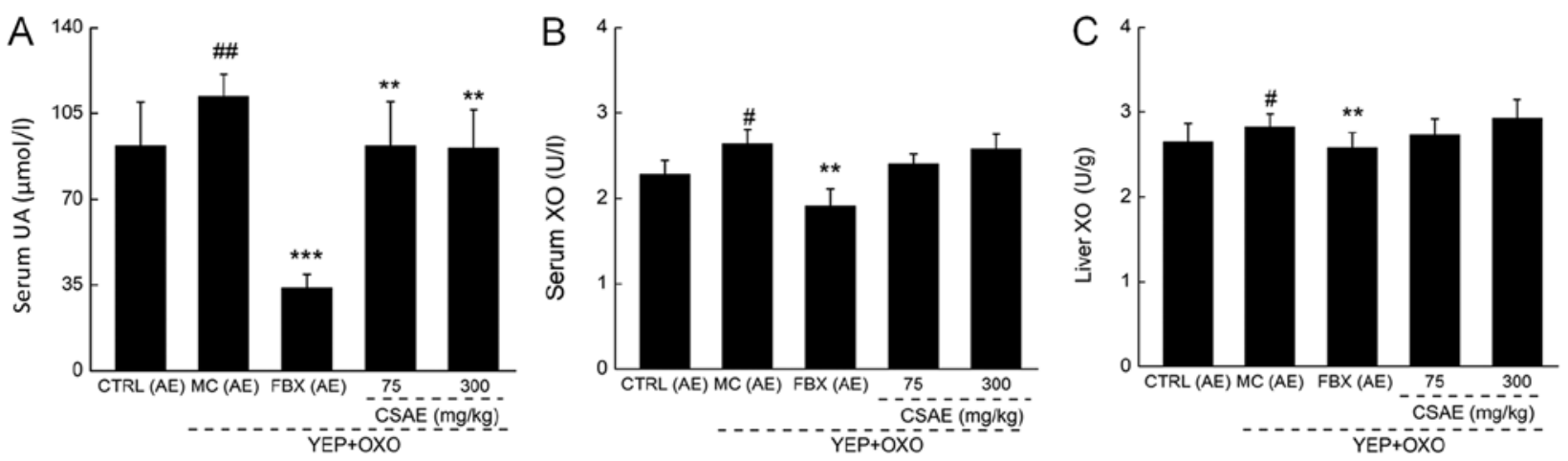

Figure 1. Effects of CSAE on mice with hyperuricemia. (A) CSAE reduced the serum levels of UA in model mice. (B and C) CSAE slightly affected XO activity in (B) serum and (C) liver of model mice. Data are expressed as the mean $\pm \mathrm{SD} ; \mathrm{n}=12 ;{ }^{\sharp} \mathrm{P}<0.05$ and ${ }^{\# \#} \mathrm{P}<0.01$ vs. CTRL $(\mathrm{AE}){ }^{* * *} \mathrm{P}<0.01$ and ${ }^{* * * *} \mathrm{P}<0.001$ vs. MC (AE). CSAE, celery seed aqueous extract; CTRL, control; FBX, MC mice treated with febuxostat; MC, hyperuricemia model mice; OXO, potassium oxonate; UA, uric acid; XO, xanthine oxidase; YEP, yeast extract powder.
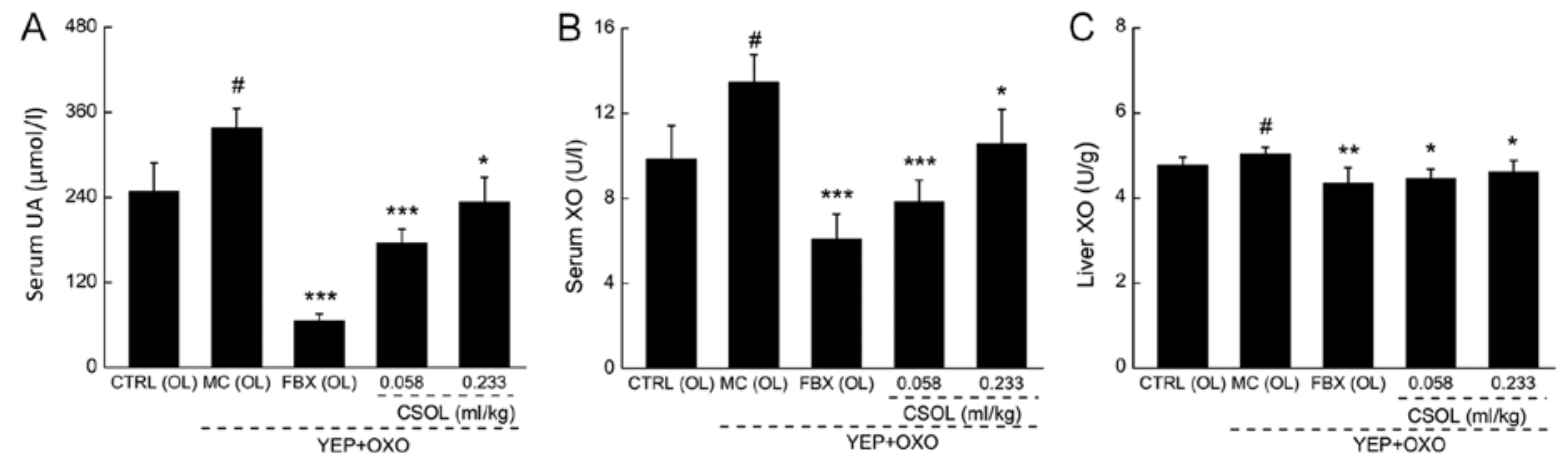

Figure 2. Effects of CSOL on mice with hyperuricemia. (A) CSOL treatment reduced the serum levels of UA in model mice. (B and C) CSOL suppressed $\mathrm{XO}$ activities in (B) serum and (C) liver in treated model mice. Data are expressed as the mean $\pm \mathrm{SD} ; \mathrm{n}=12 ;{ }^{*} \mathrm{P}<0.05$ vs. $\mathrm{CTRL}(\mathrm{OL}) ;{ }^{*} \mathrm{P}<0.05,{ }^{* * *} \mathrm{P}<0.01$ and ${ }^{* * *} \mathrm{P}<0.001$ vs. MC (OL). CSOL, celery seed oil extract; CTRL, control; FBX, MC mice treated with febuxostat; MC, model mice; OXO, potassium oxonate; UA, uric acid; XO, xanthine oxidase; YEP, yeast extract powder.

for 8 days; and v) CSOL-high group, which received $0.155 \mathrm{ml}$ CSOL $(2$ g celery seed) dissolved in $0.845 \mathrm{ml} / \mathrm{kg}$ olive oil by gavage for 8 days. CTRL (OL), MCr (OL) and FBX (OL) were used as the untreated control, model control and positive control groups, respectively, in the experiments analyzing the effects of CSOL in gouty arthritis model rats.

MSU (Sigma-Aldrich; Merck KGaA) suspension was prepared with sterile water in biological safety cabinets. The endotoxins in the MSU samples were detected by a commercial kit (Tachypleus Amebocyte Lysate for Endotoxin Detection Kit; cat. no. RG025006; Xiamen Bioendo Technology Co., Ltd.) to exclude a potential effect induced by Endotoxin. On day 6 , the rats were intra-articularly injected with $30 \mathrm{mg} / \mathrm{ml}$ MSU to the right ankle $(0.1 \mathrm{ml})$ at 4:00 PM (28), with the exception of the CTRL rats, which were injected with $0.9 \%$ saline at the same time.

Following the 8-day treatment, the right ankle circumferences of all rats were measured using Vernier calipers at 24 and $48 \mathrm{~h}$, and the swelling ratio (\%) was calculated as follows: Swelling ratio $(\%)=\left(\mathrm{C}_{\mathrm{t}}-\mathrm{C}_{0}\right) / \mathrm{C}_{0}$, where $\mathrm{C}_{\mathrm{t}}$ is the circumference at time $\mathrm{t}$, and $\mathrm{C}_{0}$ is the circumference at $0 \mathrm{~h}$. Prior to euthanasia, blood samples were collected from the caudal vein of the rats.

Biochemical assay. In the hyperuricemia MC mouse model, the serum levels of UA, and XO, and the liver levels of XO were determined using an XO Activity Assay kit (cat. no. MAK078; Sigma-Aldrich; Merck KGaA) and a UA Assay kit (cat. no. MAK077; Sigma-Aldrich; Merck KGaA) according to the manufacturer's instructions. The serum levels of reactive oxygen species (ROS; cat. no. 43124), superoxide dismutase (SOD; cat. no. 43125) and glutathione peroxidase (GSH-Px; cat. no. 43390) were determined using ELISA kits from Shanghai Yuanye Bio-Technology Co., Ltd. according to the manufacturer's instructions.

In the acute gout rat model, the serum levels of IL-1 $\beta$ (cat. no. 43360), IL-6 (cat. no/41731), IL-10 (cat. no. 41736), monocyte chemoattractant protein 1 (MCP-1; cat. no. 41640) and tumor necrosis factor $\alpha$ (TNF- $\alpha$; cat. no. 41721) were determined by ELISA kits from Shanghai Yuanye Bio-Technology Co. Ltd.

Pathological section of the ankle joint. The right ankle of each rat was collected, fixed in $4 \%$ paraformaldehyde and decalcified with $10 \%$ ethylenediaminetetraacetic acid. Following decalcification and dehydration via increasing ethanol series, followed by incubation in $50 \%$ of ethanol $+50 \%$ dimethylbenzene for $1 \mathrm{~h}$ at room temperature, samples were incubated twice with dimethylbenzene for $20 \mathrm{~min}$ at room temperature, the samples were embedded in paraffin, sliced into $5-\mu \mathrm{m}$ sections and stained with hematoxylin and eosin (H\&E). The slides were stained with hematoxylin for $5 \mathrm{~min}$ at room temperature 
Table III. Effects of CSAE on the oxidative stress-related factors in mice with hyperuricemia.

\begin{tabular}{lccc}
\hline Group & $\begin{array}{c}\text { SOD } \\
(\mathrm{U} / \mathrm{ml})\end{array}$ & $\begin{array}{c}\text { GSH-Px } \\
(\mathrm{U} / \mathrm{ml})\end{array}$ & $\begin{array}{c}\text { ROS } \\
(\mathrm{U} / \mathrm{ml})\end{array}$ \\
\hline CTRL $(\mathrm{AE})$ & $41.2 \pm 3.6$ & $61.3 \pm 7.3$ & $59.5 \pm 6.5$ \\
MC $(\mathrm{AE})$ & $36.8 \pm 3.8^{\mathrm{a}}$ & $53.6 \pm 6.1^{\mathrm{a}}$ & $64.0 \pm 3.9^{\mathrm{a}}$ \\
FBX $(\mathrm{AE})(6 \mathrm{mg} / \mathrm{kg})$ & $43.0 \pm 4.6^{\mathrm{b}}$ & $57.2 \pm 5.9$ & $54.5 \pm 59.0^{\mathrm{c}}$ \\
CSAE $(75 \mathrm{mg} / \mathrm{kg})$ & $45.1 \pm 4.7^{\mathrm{c}}$ & $61.2 \pm 4.2^{\mathrm{b}}$ & $55.3 \pm 6.1^{\mathrm{c}}$ \\
CSAE $(300 \mathrm{mg} / \mathrm{kg})$ & $47.8 \pm 3.5^{\mathrm{d}}$ & $50.2 \pm 1.9$ & $57.6 \pm 4.2^{\mathrm{b}}$ \\
\hline
\end{tabular}

${ }^{\mathrm{a}} \mathrm{P}<0.05$ vs. CTRL (AE); ${ }^{\mathrm{b}} \mathrm{P}<0.05,{ }^{\mathrm{c}} \mathrm{P}<0.01$ and ${ }^{\mathrm{d}} \mathrm{P}<0.001$ vs. $\mathrm{MC}$ (AE). Results are presented as the mean $\pm \mathrm{SD}, \mathrm{n}=12$. CSAE, celery seed aqueous extract; CTRL, control; FBX, MC mice treated with febuxostat; GSH-Px, glutathione peroxidase; ROS, reactive oxygen species; SOD, superoxide dismutase; MC, model mice.

Table IV. Effects of CSOL on the oxidative stress-related factors in mice with hyperuricemia.

\begin{tabular}{lccc}
\hline Group & $\begin{array}{c}\text { SOD } \\
(\mathrm{U} / \mathrm{ml})\end{array}$ & $\begin{array}{c}\text { GSH-Px } \\
(\mathrm{U} / \mathrm{ml})\end{array}$ & $\begin{array}{c}\text { ROS } \\
(\mathrm{U} / \mathrm{ml})\end{array}$ \\
\hline CTRL $(\mathrm{OL})$ & $24.8 \pm 2.1$ & $39.4 \pm 3.7$ & $21.1 \pm 0.7$ \\
MC $(\mathrm{OL})$ & $21.4 \pm 2.1^{\mathrm{b}}$ & $35.2 \pm 2.0^{\mathrm{a}}$ & $22.6 \pm 1.3^{\mathrm{a}}$ \\
FBX $(\mathrm{OL})(6 \mathrm{mg} / \mathrm{kg})$ & $23.2 \pm 1.9^{\mathrm{c}}$ & $36.3 \pm 4.1$ & $20.0 \pm 1.3^{\mathrm{d}}$ \\
CSOL $(0.058 \mathrm{ml} / \mathrm{kg})$ & $23.0 \pm 1.6$ & $37.8 \pm 1.2^{\mathrm{c}}$ & $20.0 \pm 1.0^{\mathrm{d}}$ \\
CSOL $(0.233 \mathrm{ml} / \mathrm{kg})$ & $25.2 \pm 1.6^{\mathrm{d}}$ & $35.6 \pm 3.7$ & $22.3 \pm 2.0$
\end{tabular}

${ }^{\mathrm{a}} \mathrm{P}<0.05$ and ${ }^{\mathrm{b}} \mathrm{P}<0.01$ vs. CTRL (OL); ${ }^{\mathrm{C}} \mathrm{P}<0.05$ and ${ }^{\mathrm{d}} \mathrm{P}<0.01$ vs. $\mathrm{MC}$ $(\mathrm{OL})$. Results are presented as the mean $\pm \mathrm{SD} ; \mathrm{n}=12$. CSOL, celery seed oil extract; CTRL, control; FBX, MC mice treated with febuxostat; GSH-Px, glutathione peroxidase; MC, model mice; ROS, reactive oxygen species; $\mathrm{SOD}$, superoxide dismutase.

and eosin for $3 \mathrm{~min}$ at room temperature and observed under a light microscope (magnification, x200), and three fields of view were examined per section.

Statistical analysis. All data are expressed as mean \pm SD Statistical analysis was performed by one-way analysis of variance followed by Dunn's multiple comparison post-hoc test using SPSS software (version 16.0; SPSS, Inc.). P<0.05 was considered to indicate a statistically significant difference.

\section{Results}

Composition of CSAE and CSOL. The CSAE contained 90.3\% total sugar, $2.73 \%$ reducing sugar, $0.515 \%$ mannitol, $4.66 \%$ protein, $0.7 \%$ crude fat and $0.014 \%$ total flavonoids (Table I). Among the 35 types of the detected fatty acids, the contents of C16:0 (0.17\%) and C18:2n6c (0.61\%) were the highest (Table I). A total of 17 different amino acids were detected in CSAE (Table I). The overall mineral content was low, and the solution contained, among other salts, $0.24 \%$ calcium and $0.0022 \%$ manganese (Table I).

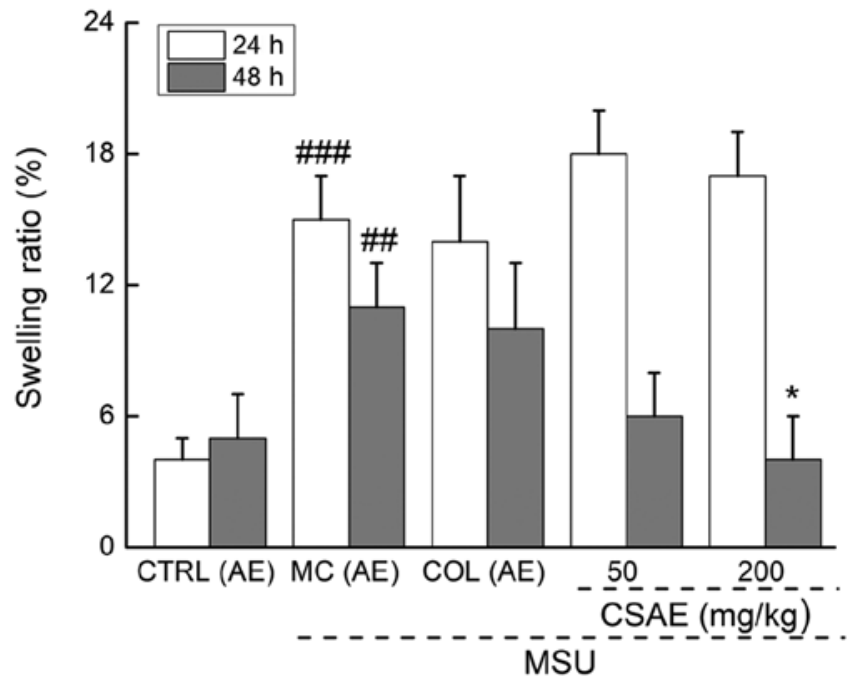

Figure 3. CSAE decreases the ankle joint swelling rate of rats with acute gouty arthritis. Data are expressed as the mean $\pm \mathrm{SD} ; \mathrm{n}=12 ;{ }^{\#} \mathrm{P}<0.01$ and

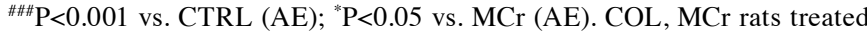
with colchicine; CSAE, celery seed aqueous extract; CTRL, control; $\mathrm{MCr}$, acute gouty arthritis model rats; MSU, monosodium urate.

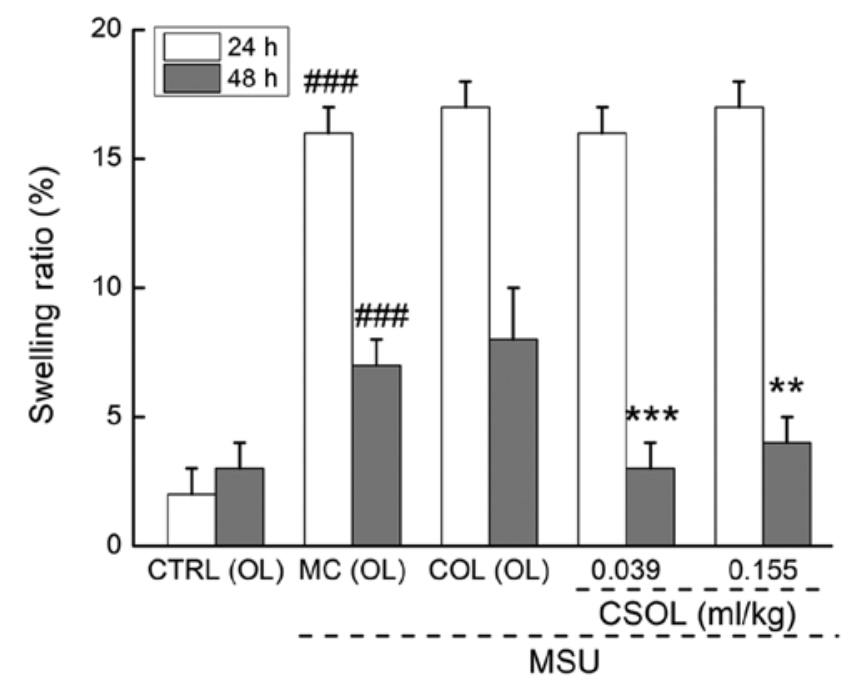

Figure 4. CSOL decreases the ankle joint swelling rate of rats with acute gouty arthritis. Data are expressed as means $\pm \mathrm{SD} ; \mathrm{n}=12 ;{ }^{\# \#} \mathrm{P}<0.001$ vs. CTRL $(\mathrm{OL}) ;{ }^{* *} \mathrm{P}<0.05$ and ${ }^{* * *} \mathrm{P}<0.01$ vs. $\mathrm{MCr}(\mathrm{OL})$. COL, $\mathrm{MCr}$ rats treated with colchicine; CSOL, celery seed oil extract; CTRL, control; $\mathrm{MCr}$, model rats; MSU, monosodium urate.

In the CSOL, among the 35 types of the detected fatty acids, the contents of $\mathrm{C} 18: 2 \mathrm{n} 6 \mathrm{c}(51.74 \%), \mathrm{C} 16: 0$ (9.8\%), $\mathrm{C} 18: 3 \mathrm{n} 3$ (3.2\%), C18:0 (2.4\%) and C18:1n9 (1.15\%) were the highest. Of the 17 amino acids identified in CSAE, only nine were detected in CSOL. The total flavonoid content in CSOL was $0.03 \%$, which included seven distinct flavonoids, including naringenin, quercetin and taxifolin (Table II).

\section{Effects of CSAE and CSOL in hyperuricemia MC mice}

Reductive effects of CSAE and CSOL on the levels of UA and $X O$. The accumulation of UA in the body induces sodium urate precipitation in the joint cavity, causing severe painful arthritis (41). In the two separate experiments, a significant 


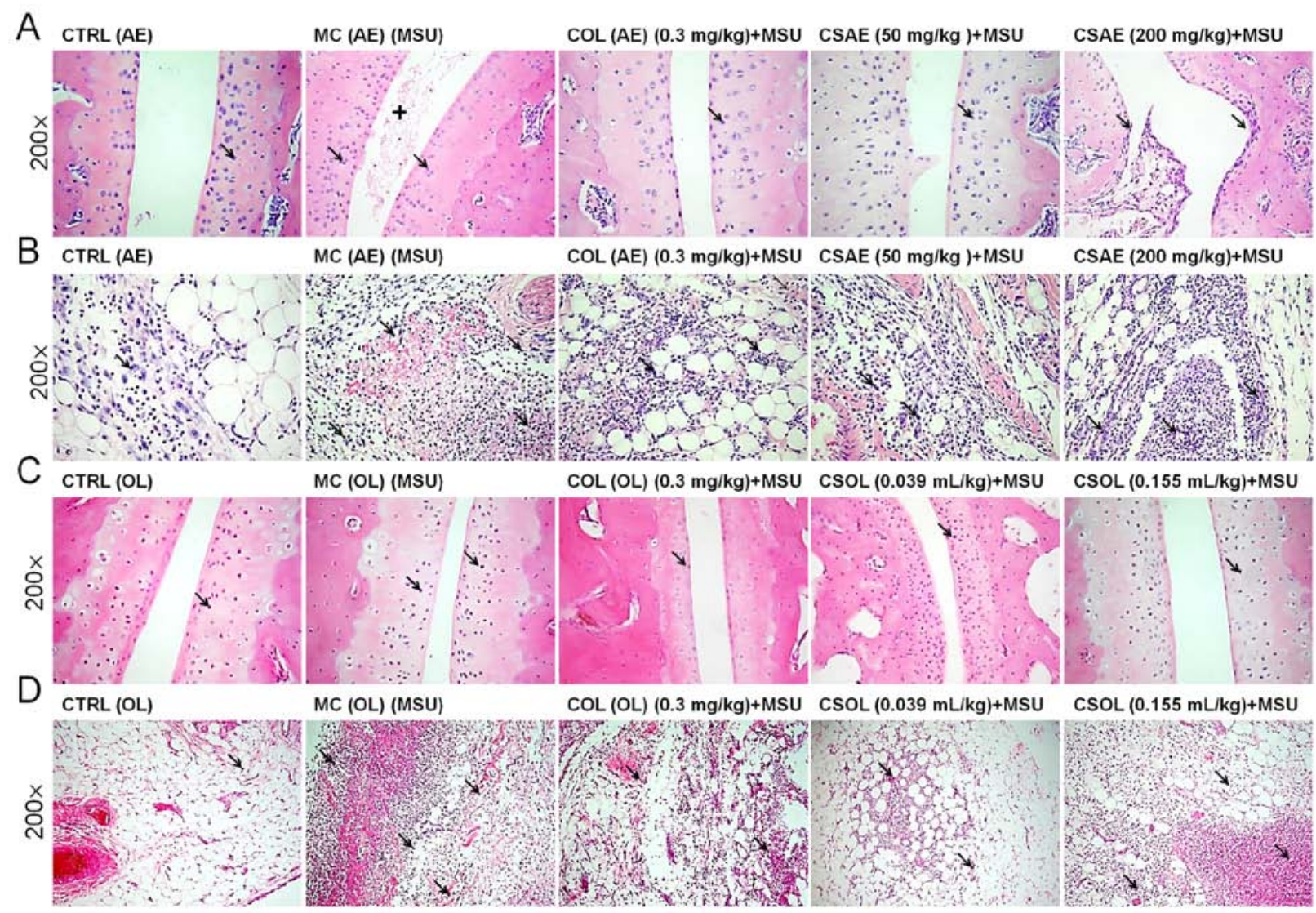

Figure 5. CSAE and CSOL reduce the pathological alterations of ankle joints in rats with acute gouty arthritis. (A and B) H\&E stained histopathological slices of (A) ankle joints and (B) joint capsules in CSAE-treated model rats. (C and D) H\&E stained histopathological slices of (C) ankle joints and (D) joint capsules of CSOL-treated model rats. Magnification, $\mathrm{x} 200 ; \mathrm{n}=6$. The arrows indicate inflammatory cells. ' + ' indicates cell debris. COL, MCr rats treated with colchicine; CSAE, celery seed aqueous extract; CSOL, celery seed oil extract; CTRL, control; MCr, model rats; MSU, monosodium urate.

increase in serum UA levels was observed in mice with hyperuricemia compared with the respective untreated CTRL mice $(\mathrm{P}<0.05$; Figs. $1 \mathrm{~A}$ and $2 \mathrm{~A})$. FBX treatments resulted in a $>60 \%$ reduction of the UA enhancement compared with the respective MC group ( $\mathrm{P}<0.001$; Figs. $1 \mathrm{~A}$ and $2 \mathrm{~A})$. Low- and high-dose CSAE and CSOL administration strongly reduced serum UA levels in mice with hyperuricemia compared with those in the respective $\mathrm{MC}$ group $(\mathrm{P}<0.05$; Figs. $1 \mathrm{~A}$ and $2 \mathrm{~A})$.

$\mathrm{XO}$ is a regulator of purine metabolism, which regulates the levels of the final product of purine metabolism, UA (42). Significantly higher levels of $\mathrm{XO}$ were observed in the serum $(\mathrm{P}<0.05$, Figs. $1 \mathrm{~B}$ and $2 \mathrm{~B})$ and liver $(\mathrm{P}<0.05$, Figs. $1 \mathrm{C}$ and $2 \mathrm{C})$ of $\mathrm{MC}$ mice compared with the CTRL group. Low- and high-dose CSAE and CSOL slightly decreased the pathologically elevated XO levels; CSOL-low treatment reduced the XO activity by $41.9 \%$ in the serum ( $\mathrm{P}<0.001$; Fig. $2 \mathrm{~B})$ and by $11.3 \%$ in the liver $(\mathrm{P}<0.05 ;$ Fig. $2 \mathrm{C})$.

Regulatory effect of CSAE and CSOL on oxidative stress. The production of UA is accompanied by a large amount of ROS, and hyperuricemia is associated with the occurrence of oxidative stress $(43,44)$. Low SOD and GSH-Px levels and high ROS levels were observed in hyperuricemia MC mice compared with the CTRL group ( $\mathrm{P}<0.05$; Tables III and IV). Low-dose CSAE treatment resulted in 14.2 and $22.6 \%$ increase of GSH-Px $(\mathrm{P}<0.05)$ and SOD $(\mathrm{P}<0.05)$ levels, respectively, and a $13.6 \%$ reduction of ROS levels $(\mathrm{P}<0.01)$ in the serum compared with untreated MC mice. Similar regulatory effects on the anti- and pro-oxidative factors were observed in the CSOL-treated compared with untreated $\mathrm{MC}$ mice $(\mathrm{P}<0.05$; Tables III and IV). However, FBX treatment only enhanced the levels of SOD and reduced the levels of ROS in the serum compared with untreated MC mice $(\mathrm{P}<0.05$; Tables III and IV).

\section{Effects of CSAE and CSOL on MSU-induced acute gouty} arthritis model rats

CSAE and CSOL regulate the swelling and pathological changes of ankle joints. Compared with the CRL rats of the two experiments, the swelling rates of the right ankle joint in the MCr rats with MSU-induced gouty arthritis increased by $>100 \%$ at 24 and $48 \mathrm{~h}(\mathrm{P}<0.001$; Figs. 3 and 4$)$. This effect was suppressed by CSAE-high and low- and high-dose CSOL administration at $48 \mathrm{~h}(\mathrm{P}<0.05$; Figs. 3 and 4$)$. Compared with $\mathrm{MCr}$ rats with MSU-induced gouty arthritis, COL treatment did not reduce the swelling ( $\mathrm{P}<0.05$; Figs. 3 and 4$)$.

In the $\mathrm{MCr}$ rats, there was a notable presence of foreign substances, such as cell debris, in the ankle joint cavity, a narrow joint space and enhanced numbers of inflammatory cells around the joint cavity were observed compared with the untreated CTRL rats of the two experiments (Fig. 5). These effects were detected in both ankle joints and joint capsules. These pathological changes of the ankle joints of rats with acute gouty arthritis appeared to be relieved by COL, CSAE-low and CSOL-low treatments (Fig. 5). However, CSAE-high and 
Table V. Effects of CSAE on inflammatory factors in MSU-induced rats with acute gout.

\begin{tabular}{lccccc}
\hline Group & IL-1 $\beta(\mathrm{pg} / \mathrm{ml})$ & IL-6 $(\mathrm{pg} / \mathrm{ml})$ & IL-10 $(\mathrm{pg} / \mathrm{ml})$ & MCP-1 $(\mathrm{pg} / \mathrm{ml})$ & TNF- $\alpha(\mathrm{pg} / \mathrm{ml})$ \\
\hline CTRL (AE) & $5.3 \pm 0.6$ & $28.1 \pm 3.2$ & $16.0 \pm 3.2$ & $116.8 \pm 11.1$ & $44.0 \pm 2.8$ \\
MCr (AE) & $6.7 \pm 1.5^{\mathrm{a}}$ & $35.3 \pm 7.9^{\mathrm{a}}$ & $13.6 \pm 1.2^{\mathrm{a}}$ & $127.1 \pm 23.9$ & $51.3 \pm 9.6$ \\
COL (AE) $(0.3 \mathrm{mg} / \mathrm{kg})$ & $5.1 \pm 0.8^{\mathrm{b}}$ & $27.4 \pm 3.7^{\mathrm{b}}$ & $14.2 \pm 1.1$ & $92.0 \pm 12.2^{\mathrm{c}}$ & $37.1 \pm 4.9^{\mathrm{c}}$ \\
CSAE $(50 \mathrm{mg} / \mathrm{kg})$ & $5.2 \pm 0.4^{\mathrm{b}}$ & $31.1 \pm 1.9$ & $16.6 \pm 1.7^{\mathrm{c}}$ & $106.9 \pm 23.7$ & $40.8 \pm 4.4^{\mathrm{b}}$ \\
CSAE $(200 \mathrm{mg} / \mathrm{kg})$ & $5.2 \pm 0.4^{\mathrm{b}}$ & $28.1 \pm 2.7^{\mathrm{b}}$ & $14.8 \pm 0.7^{\mathrm{b}}$ & $107.6 \pm 7.9$ & $42.5 \pm 3.8^{\mathrm{b}}$
\end{tabular}

${ }^{\mathrm{a}} \mathrm{P}<0.05$ vs. CTRL (AE); ${ }^{\mathrm{b}} \mathrm{P}<0.05$ and ${ }^{\mathrm{c}} \mathrm{P}<0.01$ vs. $\mathrm{MCr}(\mathrm{AE})$. Results are presented as the mean $\pm \mathrm{SD} ; \mathrm{n}=12 . \mathrm{COL}, \mathrm{MCr}$ rats treated with colchicine; CSAE, celery seed aqueous extract; CTRL, control; IL, interleukin; MCr, model rats; MCP-1, monocyte chemoattractant protein 1; TNF- $\alpha$, tumor necrosis factor $\alpha$.

Table VI. Effects of CSOL on the inflammatory factors in MSU-induced acute gouty rats.

\begin{tabular}{lccccc}
\hline Group & IL-1 $\beta(\mathrm{pg} / \mathrm{ml})$ & IL-6 $(\mathrm{pg} / \mathrm{ml})$ & IL-10 $(\mathrm{pg} / \mathrm{ml})$ & MCP-1 $(\mathrm{pg} / \mathrm{ml})$ & TNF- $\alpha(\mathrm{pg} / \mathrm{ml})$ \\
\hline CTRL $(\mathrm{OL})$ & $2.7 \pm 0.1$ & $17.7 \pm 2.9$ & $4.7 \pm 0.2$ & $73.1 \pm 3.1$ & $22.7 \pm 0.5$ \\
MCr (OL) & $3.1 \pm 0.5^{\mathrm{a}}$ & $20.4 \pm 2.1^{\mathrm{a}}$ & $4.2 \pm 0.5^{\mathrm{a}}$ & $76.5 \pm 1.1$ & $23.3 \pm 0.7$ \\
COL (OL) $(0.3 \mathrm{mg} / \mathrm{kg})$ & $2.6 \pm 0.5^{\mathrm{b}}$ & $17.1 \pm 0.9^{\mathrm{b}}$ & $4.4 \pm 0.3$ & $71.3 \pm 4.1$ & $22.2 \pm 0.8$ \\
CSOL $(0.039 \mathrm{ml} / \mathrm{kg})$ & $2.5 \pm 0.1^{\mathrm{b}}$ & $19.4 \pm 1.7$ & $5.2 \pm 0.8^{\mathrm{b}}$ & $74.0 \pm 10.2$ & $20.0 \pm 1.2^{\mathrm{b}}$ \\
CSOL $(0.155 \mathrm{ml} / \mathrm{kg})$ & $2.9 \pm 0.2^{\mathrm{b}}$ & $18.8 \pm 1.1$ & $4.8 \pm 0.2^{\mathrm{b}}$ & $72.7 \pm 2.6$ & $21.5 \pm 1.0$ \\
\hline
\end{tabular}

${ }^{\mathrm{a}} \mathrm{P}<0.05$ vs. $\mathrm{CTRL}(\mathrm{OL}) ;{ }^{\mathrm{b}} \mathrm{P}<0.05$ vs. $\mathrm{MCr}(\mathrm{OL})$. Results are presented as the mean $\pm \mathrm{SD} ; \mathrm{n}=12$. COL, MCr rats treated with colchicine; $\mathrm{CSOL}$, celery seed oil extract; CTRL, control; IL, interleukin; MCr, model rats; MCP-1, monocyte chemoattractant protein 1; TNF- $\alpha$, tumor necrosis factor $\alpha$.

CSOL-high failed to relieve the inflammation of the joints (Fig. 5), possibly due to a negative feedback regulation.

Effects of CSAE and CSOL on inflammatory factors. A previous study has demonstrated that the pathogenesis of gout is associated with inflammation (45). Compared with the CTRL rats of the two experiments, enhanced levels of the pro-inflammatory cytokines IL- $1 \beta$ and IL- 6 and reduced levels of the anti-inflammatory cytokine IL-10 were observed in the respective hyperuricemia or gouty arthritis $\mathrm{MCr}$ rats $(\mathrm{P}<0.05$; Tables V and VI). CSAE-high reduced the levels of IL- $1 \beta$ by $22.4 \%(\mathrm{P}<0.05)$, IL- 6 by $20.4 \%(\mathrm{P}<0.05)$ and TNF- $\alpha$ by $17.2 \%$ $(\mathrm{P}<0.05)$, and enhanced the IL-10 levels by $8.8 \%(\mathrm{P}<0.05)$ compared with untreated $\mathrm{MCr}$ rats; however, it did not affect the levels of MCP-1 in the serum of rats with acute gouty arthritis (Table V). CSOL-low resulted in 14.2 and $19.4 \%$ reductions in the serum levels of TNF- $\alpha(\mathrm{P}<0.05)$ and IL- $1 \beta$ $(\mathrm{P}<0.05)$, respectively, and $\mathrm{a}>14.3 \%$ increase in the serum levels of IL-10 $(\mathrm{P}<0.05)$ compared with untreated acute gouty arthritis $\mathrm{MCr}$ rats (Table VI). CSOL did not affect the levels of IL-6 or MCP-1 in rats with acute gouty arthritis (Table VI).

\section{Discussion}

The results of the present study suggested that CSAE and CSOL exerted slightly suppressive effects on the serum UA levels and $\mathrm{XO}$ activity in mice with hyperuricemia induced by OXO and yeast extract, and reduced the ankle joint swelling rates in rats with acute gouty arthritis induced by an intra-articular injection of MSU.

The occurrence of hyperuricemia increases the production of oxygen free radicals, promotes lipid peroxidation and upregulates pro-inflammatory factor expression $(6,46-48)$. Celery juice and celery root can increase the antioxidant content in rats (49). One of the major functions of the flavonoids in plants is to scavenge free radicals and exert anti-oxidant effects $(50,51)$. In the present study, CSAE and CSOL, which contain various types of flavonoids, such as quercetin and taxifolin, inhibited XO activity, promoted oxidative stress factors SOD and GSH-Px and reduced levels of ROS in mice with hyperuricemia mice. As an effective antioxidant enzyme, SOD catalyzes the rapid conversion of $\mathrm{O}_{2}$ and $\bullet \mathrm{O}_{2}{ }^{-}$to $\mathrm{H}_{2} \mathrm{O}_{2}$, following which $\mathrm{H}_{2} \mathrm{O}_{2}$ can be converted to $\mathrm{H}_{2} \mathrm{O}$ by GSH-Px catalysis inside cells (52). A negative correlation between the levels of XO activity and SOD and GSH-Px has been reported in patients with acute paraquat poisoning (53). Flaxseed oil has been demonstrated to inhibit the gene expression levels of XO by increasing the activity of SOD and GSH-Px in the brains of female rats treated with g-irradiation and carbon tetrachloride (54). XO is a key enzyme in the catalytic conversion of xanthine and hypoxanthine to UA $(55,56)$, which is responsible for the generation of ROS (43). As a feedback response, a large amount of ROS is generated alongside the production of UA (43). Therefore, the suppressive effects of CSEA and CSOL on UA in mice with hyperuricemia may be, at least partially, associated with oxidative stress inhibition. 
During the development of gouty arthritis, MSU enters cells through endocytosis and induces inflammation (57). MSU stimulates synovial cells, monocyte macrophages and neutrophils to produce IL-1 $\beta$, which promotes the release of a series of inflammatory cytokines, such as IL-6, TNF- $\alpha$ and MCP-1 (41), leading to the spread of inflammation (58). In clinical trials, high levels of pro-inflammatory factors, especially IL-1 $\beta$, have been detected in patients with gout (59). IL-1 $\beta$ has been investigated for its important roles in gout, and piperine has been shown to exhibit anti-gouty arthritis effect by inhibiting IL-1 $\beta$ (60). IL-1 inhibitors, such as anakinra and canakinumab, which are drugs approved by the U.S. Food and Drug Administration and the European Medicines Agency (61), are reportedly effective against gouty arthritis $(62,63)$. In addition, sustained oxidative stress can lead to chronic inflammation (64). The overproduction of ROS is a pathogenetic factor of acute gouty arthritis $(65,66)$. Excessive ROS production activates the inflammasome, specifically NACHT, LRR and PYD domains-containing protein 3, and promotes the production of IL-1 $\beta$ in gouty arthritis (67). In the present study, CSAE and CSOL reduced the pro-inflammatory factors and enhanced the anti-inflammatory factor in the serum, and mitigated the pathological changes of the ankle joints of rats with MSU-induced acute gouty arthritis. The results of the present study suggested that the anti-inflammatory properties of CSAE and CSOL, as well as their modulatory effect on inflammatory cytokines, especially IL-1 $\beta$, may be central to their anti-gout effects, possibly through the modulation of oxidative stress.

There were certain limitations to the present study. Although the anti-gout effects of two celery seed extracts, CSAE and CSOL, were demonstrated in two rodent models, the results did not clearly determine which extract exhibited stronger effects. The contents of CSAE and CSOL were systematically detected; however, which component exhibited the anti-gouty arthritis and anti-hyperuricemia properties remains to be determined. Based on the current data, it is difficult to establish quality standards for CSAE and CSOL. Additionally, although the anti-gout effects of CSAE and CSOL were demonstrated to be related to antioxidation and anti-inflammation, the detailed mechanisms require further systematic investigation.

In conclusion, the present study demonstrated that CSAE and CSOL exhibited the effect of suppressing serum UA levels in mice with hyperuricemia and the swelling rates of ankle joints in rats with gouty arthritis, which may be associated with the modulation of $\mathrm{XO}$ activity and inflammation response by oxidative stress regulation, providing experimental evidence to support the further evaluation of CSAE and CSOL as agents for gout treatment.

\section{Acknowledgements}

Not applicable.

\section{Funding}

The present study was supported by The National Key Research and Development Program of China (grant no. 2018YFE0107800), The Special Projects of Cooperation between Jilin University and Jilin Province in
China (grant no. SXGJSF2017-1), The '13th Five-year' Science and Technology Project from the Education Department in Jilin Province (grant no. JJKH20190108KJ) and The Tianjin Municipal Science and Technology Commission (grant no. 16JCQNJC09100).

\section{Availability of data and materials}

The datasets used and/or analyzed during the current study are available from the corresponding author on reasonable request.

\section{Authors' contributions}

DW and NH designed the experiments; SL, LL, HY, XJ and WH performed the experiments; SL, LL and HY processed data; DW, SL and LL wrote the paper; DW and NH revised the paper.

\section{Ethics approval and consent to participate}

The experimental animal protocol was approved by the Animal Ethics Committee of Jilin University (Changchun, China; approval no. 20171124).

\section{Patient consent for publication}

Not applicable.

\section{Competing interests}

The authors declare that they have no competing interests.

\section{References}

1. Chen LX and Schumacher HR: Gout: An evidence-based review. J Clin Rheumatol 14 (5 Suppl): S55-S62, 2008.

2. Kuo CF, Grainge MJ, Mallen C, Zhang W and Doherty M: Rising burden of gout in the UK but continuing suboptimal management: A nationwide population study. Ann Rheum Dis 74: 661-667, 2015.

3. Trifirò G, Morabito P, Cavagna L, Ferrajolo C, Pecchioli S, Simonetti M, Bianchini E, Medea G, Cricelli C, Caputi AP and Mazzaglia G: Epidemiology of gout and hyperuricaemia in Italy during the years 2005-2009: A nationwide population-based study. Ann Rheum Dis 72: 694-700, 2013.

4. Liu S, Perez-Ruiz F and Miner JN: Patients with gout differ from healthy subjects in renal response to changes in serum uric acid. Joint Bone Spine 84: 183-188, 2017.

5. Lin Y, Liu PG, Liang WQ, Hu YJ, Xu P, Zhou J, Pu JB and Zhang HJ: Luteolin-4'-O-glucoside and its aglycone, two major flavones of Gnaphalium affine D. Don, resist hyperuricemia and acute gouty arthritis activity in animal models. Phytomedicine 41: 54-61, 2018.

6. Terkeltaub R: Update on gout: New therapeutic strategies and options. Nat Rev Rheumatol 6: 30-38, 2010.

7. Cronstein BN and Terkeltaub R: The inflammatory process of gout and its treatment. Arthritis Res Ther 8 (Suppl 1): S3, 2006.

8. Martinon F, Petrilli V, Mayor A, Tardivel A and Tschopp J: Gout-associated uric acid crystals activate the NALP3 inflammasome. Nature 440: 237-241, 2006.

9. Terkeltaub R: Update on gout: New therapeutic strategies and options. Nat Rev Rheumatol 6: 30-38, 2010

10. Dalbeth $\mathrm{N}$ and Haskard DO: Mechanisms of inflammation in gout. Rheumatology (Oxford, England) 44: 1090-1096, 2005.

11. Bai H, Yang B, Yu W, Xiao Y, Yu D and Zhang Q: Cathepsin B links oxidative stress to the activation of NLRP3 inflammasome. Exp Cell Res 362: 180-187, 2018.

12. Terkeltaub RA: Colchicine update: 2008. Semin Arthritis Rheum 38: 411-419, 2009.

13. Fam AG: Strategies and controversies in the treatment of gout and hyperuricaemia. Baillieres Clin Rheumatol 4: 177-192, 1990. 
14. Terkeltaub R, Bushinsky DA and Becker MA: Recent developments in our understanding of the renal basis of hyperuricemia and the development of novel antihyperuricemic therapeutics. Arthritis Res Ther 8 (Suppl): S4, 2006.

15. Fam AG: Difficult gout and new approaches for control of hyperuricemia in the allopurinol-allergic patient. Curr Rheumatol Rep 3: 29-35, 2001.

16. Fam AG: Treating acute gouty arthritis with selective COX 2 inhibitors. BMJ 325: 980-981, 2002.

17. Salihu Shinkafi T, Bello L, Wara Hassan S and Ali S: An ethnobotanical survey of antidiabetic plants used by Hausa-Fulani tribes in Sokoto, Northwest Nigeria. J Ethnopharmacol 172: 91-99, 2015.

18. Gauri M, Ali SJ and Khan MS: A Review of Apium graveolens (Karafs) with special reference to Unani Medicine. IAIM 2: 131-136, 2015.

19. Kooti W, Ghasemiboroon M, Asadi-Samani M, Ahangarpoor A, Abadi MAN, Afrisham R and Dashti N: The effects of hydro-alcoholic extract of celery on lipid profile of rats fed a high fat diet. Adv Environmental Biol 8: 325-330, 2014.

20. Gharooni M and Sarkarati AR: Application of Apium Graveolens in treatment of hypertension. Tehran Univ Med J 58: 67-69, 2000.

21. Mencherini T, Cau A, Bianco G, Della Loggia R, Aquino RP and Autore G: An extract of Apium graveolens var. dulce leaves: Structure of the major constituent, apiin and its anti-inflammatory properties. J Pharm Pharmacol 59: 891-897, 2007.

22. Momin RA and Nair MG: Mosquitocidal, nematicidal, and antifungal compounds from Apium graveolens L. seeds. J Agric Food Chem 49: 142-145, 2001.

23. Al-Howiriny T, Alsheikh A, Alqasoumi S, Al-Yahya M, ElTahir K and Rafatullah S: Gastric antiulcer, antisecretory and cytoprotective properties of celery (Apium graveolens) in rats. Pharm Biol 48: 786-793, 2014

24. Jabbar AA, Al-Sa'aidi and Alrodhan M: Antioxidant activity of n-butanol extract of celery (Apium graveolens) seed in streptozotocin-induced diabetic male rats. Res Pharm Biotechnol 4 24-29, 2012.

25. Al-Okbi D: Evaluation of anti-gout activity of some plant food extracts. Pol J Food Nutr Sci 58: 389-395, 2008

26. Zhou Q, Lin FF, Liu SM and Sui XF: Influence of the total saponin fraction from Dioscorea nipponica Makino on TLR2/4-IL1R receptor singnal pathway in rats of gouty arthritis. J Ethnopharmacol 206: 274-282, 2017.

27. Amat N, Umar A, Hoxur P, Anaydulla M, Imam G, Aziz R, Upur H, Kijjoa A and Moore N: Traditional Uighur medicine Karapxa decoction, inhibits liver xanthine oxidase and reduces serum uric acid concentrations in hyperuricemic mice and scavenges free radicals in vitro. BMC Complement Altern Med 15: $131,2015$.

28. Li L, Teng M, Liu Y, Qu Y, Zhang Y, Lin F and Wang D: Anti-gouty arthritis and antihyperuricemia effects of sunflower (Helianthus annuus) head extract in gouty and hyperuricemia animal models. Biomed Res Int 2017: 5852076, 2017.

29. Chow PS and Landhäusser SM: A method for routine measurements of total sugar and starch content in woody plant tissues. Tree Physiol 24: 1129-1136, 2004.

30. Lee GO, Kosek P, Lima AA, Singh R, Yori PP, Olortegui MP, Lamsam JL, Oliveira DB, Guerrant RL and Kosek M: Lactulose: Mannitol diagnostic test by HPLC and LC-MSMS platforms: Considerations for field studies of intestinal barrier function and environmental enteropathy. J Pediatr Gastroenterol Nutr 59: 544-550, 2014

31. McKee LS: Measuring enzyme kinetics of glycoside hydrolases using the 3,5-dinitrosalicylic acid assay. Methods Mol Biol 1588 27-36, 2017.

32. Chromý V, Vinklárková B, Šprongl L and Bittová M: The Kjeldahl method as a primary reference procedure for total protein in certified reference materials used in clinical chemistry. I. A review of Kjeldahl methods adopted by laboratory medicine. Crit Rev Anal Chem 45: 106-111, 2015.

33. Smith CR and Tschinkel WR: Ant fat extraction with a Soxhlet extractor. Cold Spring Harb Protoc 2009: pdb.prot5243, 2009.

34. Zhang D,Zheng XY, YanXW,CaoWGand Gang W: Determination of Total Flavonoids and Rutin in Ephorbia helioscopia L. from Chongqing. Med Plant 2: 30-32, 45, 2011

35. Li JJ, Hu XQ, Zhang XF, Liu JJ and Cao LS: Study on variation of main ingredients from spores and fruiting bodies of Ganoderma lucidum. Zhongguo Zhong Yao Za Zhi 39: 4246-4251, 2014 (In Chinese).
36. Silva EDS, da Silva EGP, Silva DDS, Novaes CG, Amorim FAC Dos Santos MJS and Bezerra MA: Evaluation of macro and micronutrient elements content from soft drinks using principal component analysis and Kohonen self-organizing maps. Food Chem 273: 9-14, 2019

37. Zhang ZX, Lu Y, Li HP, Tu Y, Liu BY and Yang ZG: Assessment of heavy metal contamination, distribution and source identification in the sediments from the Zijiang River, China. Sci Total Environ 645: 235-243, 2018.

38. Huang FF, Jiang SJ, Chen YL and Sahayam AC: Chemical vapor generation sample introduction for the determination of $\mathrm{As}, \mathrm{Cd}$, $\mathrm{Sb}, \mathrm{Hg}$, and $\mathrm{Pb}$ in nail polish by inductively coupled plasma mass spectrometry. Spectroc Acta Part B Atom Spectr 140: 84-88, 2018.

39. Sanchez-Lozada LG, Tapia E, Bautista-Garcia P, Soto V, Avila-Casado C, Vega-Campos IP, Nakagawa T, Zhao L, Franco M and Johnson RJ: Effects of febuxostat on metabolic and renal alterations in rats with fructose-induced metabolic syndrome. Am J Physiol Renal Physiol 294: F710-F718, 2008.

40. Toker H, Yuce HB, Yildirim A, Tekin MB and Gevrek F: The effect of colchicine on alveolar bone loss in ligature-induced periodontitis. Braz Oral Res 33: e001, 2019.

41. Sabina EP and Rasool M: An in vivo and in vitro potential of Indian ayurvedic herbal formulation Triphala on experimental gouty arthritis in mice. Vascul Pharmacol 48: 14-20, 2008.

42. Merriman TR: An update on the genetic architecture of hyperuricemia and gout. Arthritis Res Ther 17: 98, 2015.

43. Oguz N, Kirca M, Cetin A and Yesilkaya A: Effect of uric acid on inflammatory COX-2 and ROS pathways in vascular smooth muscle cells. J Recept Signal Transduct Res 37: 500-505, 2017.

44. Tang L, Xu Y, Wei Y and He X: Uric acid induces the expression of TNFa via the ROSMAPKNF- $\kappa$ B signaling pathway in rat vascular smooth muscle cells. Mol Med Rep 16: 6928-6933, 2017.

45. Dalbeth N, Merriman TR and Stamp LK: Gout. Lancet 388: 2039-2052, 2016

46. Singh M, Kalia AN, Sharma R and Balakumar P: Hyperuricemia: Is it a risk factor for vascular endothelial dysfunction and associated cardiovascular disorders? Current Hypertension Rev 5: 1-6, 2009.

47. Billiet L, Doaty S, Katz JD and Velasquez MT: Review of hyperuricemia as new marker for metabolic syndrome. ISRN Rheumatol 2014: 852954, 2014

48. Kanellis J, Watanabe S, Li JH, Kang DH, Li P, Nakagawa T, Wamsley A, Sheikh-Hamad D, Lan HY, Feng L and Johnson RJ: Uric acid stimulates monocyte chemoattractant protein-1 production in vascular smooth muscle cells via mitogen-activated protein kinase and cyclooxygenase-2. Hypertension 41: 1287-1293, 2003.

49. Kolarovic J, Popovic M, Zlinská J, Trivic S and Vojnovic M: Antioxidant activities of celery and parsley juices in rats treated with doxorubicin. Molecules 15: 6193-6204, 2010.

50. Nickavar B, Kamalinejad M and Izadpanah H: In vitro free radical scavenging activity of five Salvia species. Pak J Pharm Sci 20: 291-294, 2007

51. Yao Y, Sang W, Zhou M and Ren G: Phenolic composition and antioxidant activities of 11 celery cultivars. J Food Sci 75: C9-C13, 2010.

52. Song Y, Driessens N, Costa M, De Deken X, Detours V, Corvilain B, Maenhaut C, Miot F, Van Sande J, Many MC and Dumont JE: Roles of hydrogen peroxide in thyroid physiology and disease. J Clin Endocrinol Metab 92: 3764-3773, 2007.

53. Zhang J, Lv G and Zhao Y: The significance of serum xanthine oxidase and oxidation markers in acute paraquat poisoning in humans. Clin Biochem 44: 221-225, 2011.

54. Ismail AF, Salem AA and Eassawy MM: Modulation of gamma-irradiation and carbon tetrachloride induced oxidative stress in the brain of female rats by flaxseed oil. J Photochem Photobiol B 161: 91-99, 2016.

55. Ramallo IA, Zacchino SA and Furlan RL: A rapid TLC autographic method for the detection of xanthine oxidase inhibitors and superoxide scavengers. Phytochem Anal 17: 15-19, 2006

56. Unno T, Sugimoto A and Kakuda T: Xanthine oxidase inhibitors from the leaves of Lagerstroemia speciosa (L.) Pers. J Ethnopharmacol 93: 391-395, 2004.

57. Rock KL, Kataoka H and Lai JJ: Uric acid as a danger signal in gout and its comorbidities. Nat Rev Rheumatol 9: 13-23, 2013.

58. Jeong JH, Hong S, Kwon OC, Ghang B, Hwang I, Kim YG, Lee CK and Yoo B: CD14 ${ }^{+}$cells with the phenotype of infiltrated monocytes consist of distinct populations characterized by anti-inflammatory as well as pro-inflammatory activity in gouty arthritis. Front Immunol 8: 1260, 2017.

59. Zeng M, Dang W, Chen B, Qing Y, Xie W, Zhao M and Zhou J: IL-37 inhibits the production of pro-inflammatory cytokines in MSU crystal-induced inflammatory response. Clin Rheumatol 35: 2251-2258, 2016. 
60. Sabina EP, Nagar S and Rasool M: A role of piperine on monosodium urate crystal-induced inflammation-an experimental model of gouty arthritis. Inflammation 34: 184-192, 2011.

61. Dhimolea E: Canakinumab. Mabs 2: 3-13, 2010.

62. So A, De Smedt T, Revaz S and Tschopp J: A pilot study of IL-1 inhibition by anakinra in acute gout. Arthritis Res Ther 9: R28, 2007.

63. Schlesinger N, De Meulemeester M, Pikhlak A, Yücel AE, Richard D, Murphy V, Arulmani U, Sallstig P and So A: Canakinumab relieves symptoms of acute flares and improves health-related quality of life (HRQoL) in difficult-to-treat gouty arthritis patients by suppressing inflammation: Results of a randomized, dose-ranging study. Arthritis Res Ther 13: R53, 2011.

64. Mittal M, Siddiqui MR, Tran K, Reddy SP and Malik AB: Reactive oxygen species in inflammation and tissue injury. Antioxid Redox Signal 20: 1126-1167, 2014.

65. Murunikkara V and Rasool M: Trikatu, a herbal compound that suppresses monosodium urate crystal-induced inflammation in rats, an experimental model for acute gouty arthritis. Cell Biochem Funct 32: 106-114, 2014.
66. Sabina EP, Rasool M, Mathew L, Ezilrani P and Indu H: 6-Shogaol inhibits monosodium urate crystal-induced inflammation-an in vivo and in vitro study. Food Chem Toxicol 48: 229-235, 2010

67. Li S, Wu H, Han D, Ma S, Fan W, Wang Y, Zhang R, Fan M, Huang Y, Fu X and Cao F: A novel mechanism of mesenchymal stromal cell-mediated protection against sepsis: Restricting inflammasome activation in macrophages by increasing mitophagy and decreasing mitochondrial ROS. Oxid Med Cell Longev 2018: 3537609, 2018.

(i) (9) This work is licensed under a Creative Commons Attribution-NonCommercial-NoDerivatives 4.0 International (CC BY-NC-ND 4.0) License. 